\title{
Assessment of water quality: a case study of the Seybouse River (North East of Algeria)
}

\author{
M. Guettaf - A. Maoui $\cdot$ Z. Ihdene
}

Received: 10 March 2014/ Accepted: 16 October 2014/Published online: 13 November 2014

(c) The Author(s) 2014. This article is published with open access at Springerlink.com

\begin{abstract}
The assessment of water quality has been carried out to determine the concentrations of different ions present in the surface waters. The Seybouse River constitutes a dump of industrial and domestic rejections which contribute to the degradation of water quality. A total of 48 surface water samples were collected from different stations. The first objective of this study is the use of water quality index (WQI) to evaluate the state of the water in this river. The second aim is to calculate the parameters of the quality of water destined for irrigation such as sodium adsorption ratio, sodium percentage, and residual sodium carbonate. A high mineralization and high concentration of major chemical elements and nutrients indicate inevitably a high value of WQI index. The mean value of electrical conductivity is about $945.25 \mu \mathrm{s} / \mathrm{cm}$ in the station 2 (Bouhamdane) and exceeds $1,400 \mu \mathrm{s} / \mathrm{cm}$ in station 12 of Nador. The concentration of sulfates is above $250 \mathrm{mg} / \mathrm{l}$ in the stations 8 (Zimba) and 11 (Helia). A concentration of orthophosphate over $2 \mathrm{mg} / \mathrm{l}$ was observed in the station 11 . The comparison of the obtained and the WHO standards indicates a before using it use in agricultural purposes.
\end{abstract}

\section{Guettaf}

Department of Biology, University of 8 May 1945, BP 401

Guelma, Algeria

e-mail: abdelyakine23@yahoo.fr

A. Maoui $(\square)$

Laboratory of Civil Engineering and Hydraulics, University of 8

May 1945, BP 401 Guelma, Algeria

e-mail: maoui_ammar@yahoo.fr

Z. Ihdene

Laboratory of Macromolecular-Chemistry UERCA-EMP, BP 17

C Bordj El Bahri, Algiers, Algeria
Keywords Seybouse River · Hydrochemistry · Pollution . Algeria

\section{Introduction}

In Algeria, the quality of rivers is deteriorated by various forms of pollution. Water resources have become increasingly limited, difficult to exploit, and often are exposed to significant amounts of wastewater. The water quality index (WQI) is a method among other methods used for assessing the portability of water. Knowing this index facilitates the communication of the global state of water quality in a given area and informs the population and the administration (Bordalo et al. 2006; Gold et al. 2003; Nives 1999). The WQI is based on a mathematical relation that transforms several physico-chemical parameters of waters into a single number, which, in turn represents the level of water quality. The concept of water quality to categorize water according to its degree of purity or pollution dates back to 1848 in Germany (Dojlido and Best 1993; Horton 1965) is to be credited to give a first formal definition to it. The WQI approach has been applied in many countries such as India (Tiwari and Mishra 1985), United States (Canter 1996), Indonesia (Gatot and Rina 2011), Canada (CCMC 2001) and Malaysia (Munirah et al. 2011) to control the quality of surface and groundwater. Specific indices of water quality, have been developed in many countries, such as the national sanitation foundation water quality index (NSFWQI) in the United States developed by the national sanitation foundation (Detroit, Michigan) and the British Columbia water quality index (BCWQI) by the British Columbia ministry of environment of 


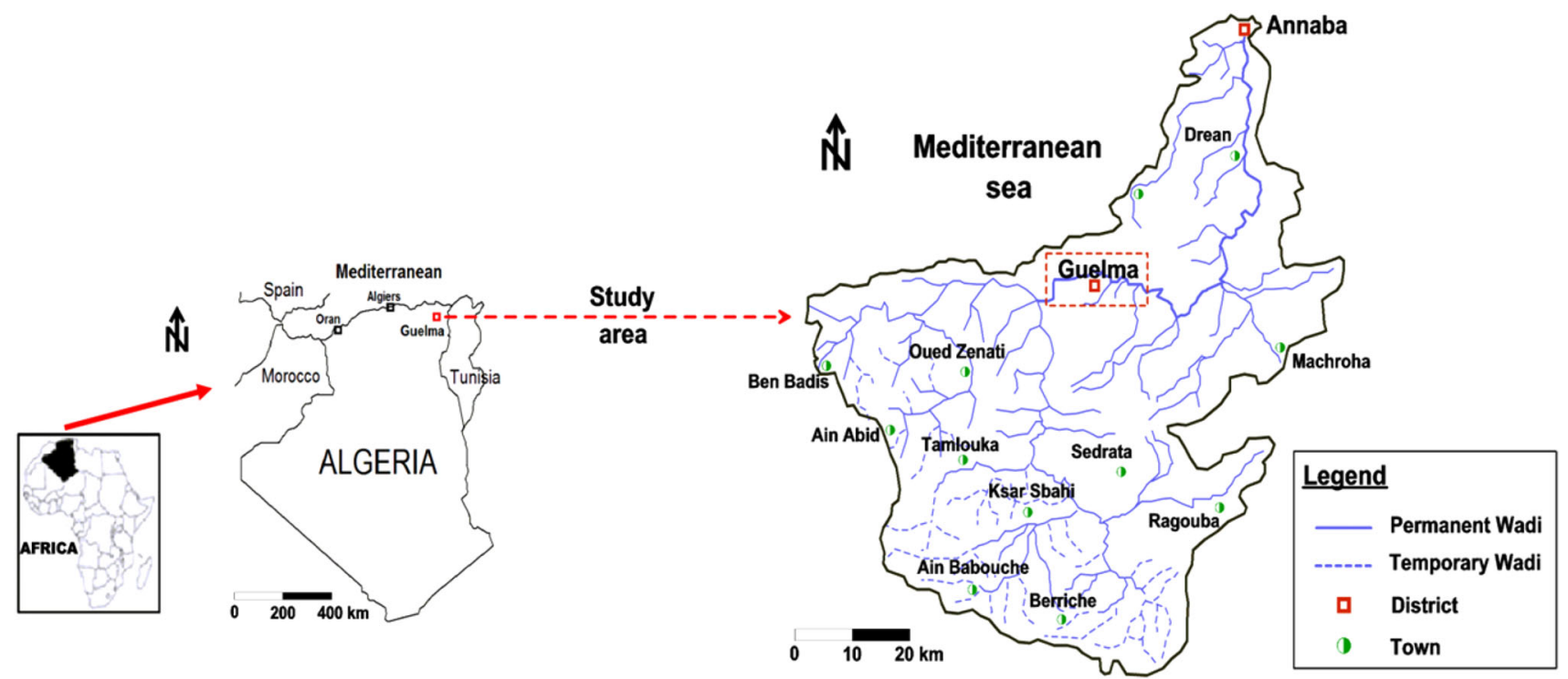

Fig. 1 Geographical situation of study area

Canada (Vancouver, Canada) (Said et al. 2004). WQI is defined as a rating that reflects the composite influence of different water quality parameters (Sahu and Sikdar 2008). The aim of this study is to use WQI not as an absolute measure of degree of pollution or the actual water quality but as a tool for evaluating an approximation or general health of a river.

The classification of water quality is done punctually according to the European standards in Africa and particularly in Algeria. The Seybouse River drains into the Mediterranean Sea, over $240 \mathrm{~km}$ from its source. Because of the demographic and industrial growth in the area during the last decade, this river receives a significant part of urban, industrial, and agricultural residues, considerably damaging the environment. To determine the WQI, a physical and chemical characterization of the Seybouse River water is carried out in the region of Guelma (Fig. 1).

\section{Materials and methods}

\section{Study area}

The Seybouse watershed is situated in the extreme North East of Algeria with a surface of about $6,471 \mathrm{~km}^{2}$. This basin extends on three districts Guelma, Annaba, and El Taref, with a population of about 1,500,000 inhabitants. The basin is limited by the Mediterranean Sea in the North, by the district of Souk Ahras in the South, by the Fetzara Lake and the Edough Massif in West, and the Mafragh River in the East. The Seybouse River constitutes an important superficial water resource with a total length of $240 \mathrm{~km}$ (Fig. 1). Its water contributes in the irrigation of the plains of both Guelma and Annaba provinces. The variation of the annual precipitation affects its hydrological regime; for instance, the floods of 1985 caused many damages to the Seybouse Valley. The drought observed in the last decades is linked to the decrease of the annual precipitation which did not exceed $600 \mathrm{~mm}$ by year.

The study area is located in the middle of the Seybouse Basin. With regard to climate, the area is characterized by an annual average rainfall of $600 \mathrm{~mm}$, a more or less cool winter and a hot dry summer. Geologically, the area constitutes a basin of collapse full of plio-quaternary detritus deposits (rollers, gravels, and sands with clays standing on substratum constituted of Miocene marls. All over the Seybouse watershed (Fig. 2), the plio-quaternary is made of alluvia deposits with interspersions of gypsiferous and saliferous formations (vila 1980).

Sampling and analyses

The hydro-chemical analysis was based on 12 sampling stations (Fig. 3). 48 samples were collected from the Seybouse River during four periods (April and August in 2010, January and April 2011). They were collected into new polyethylene bottles that had been rinsed two or three times with the water to be analyzed. The bottles were filled until overflowing and closed underwater to minimize aeration. All bottles were carefully labeled and numbered prior to transport and kept at low temperature $4{ }^{\circ} \mathrm{C}$. Physico-chemical parameters (temperature, $\mathrm{pH}$, and $\mathrm{EC}$ ) 


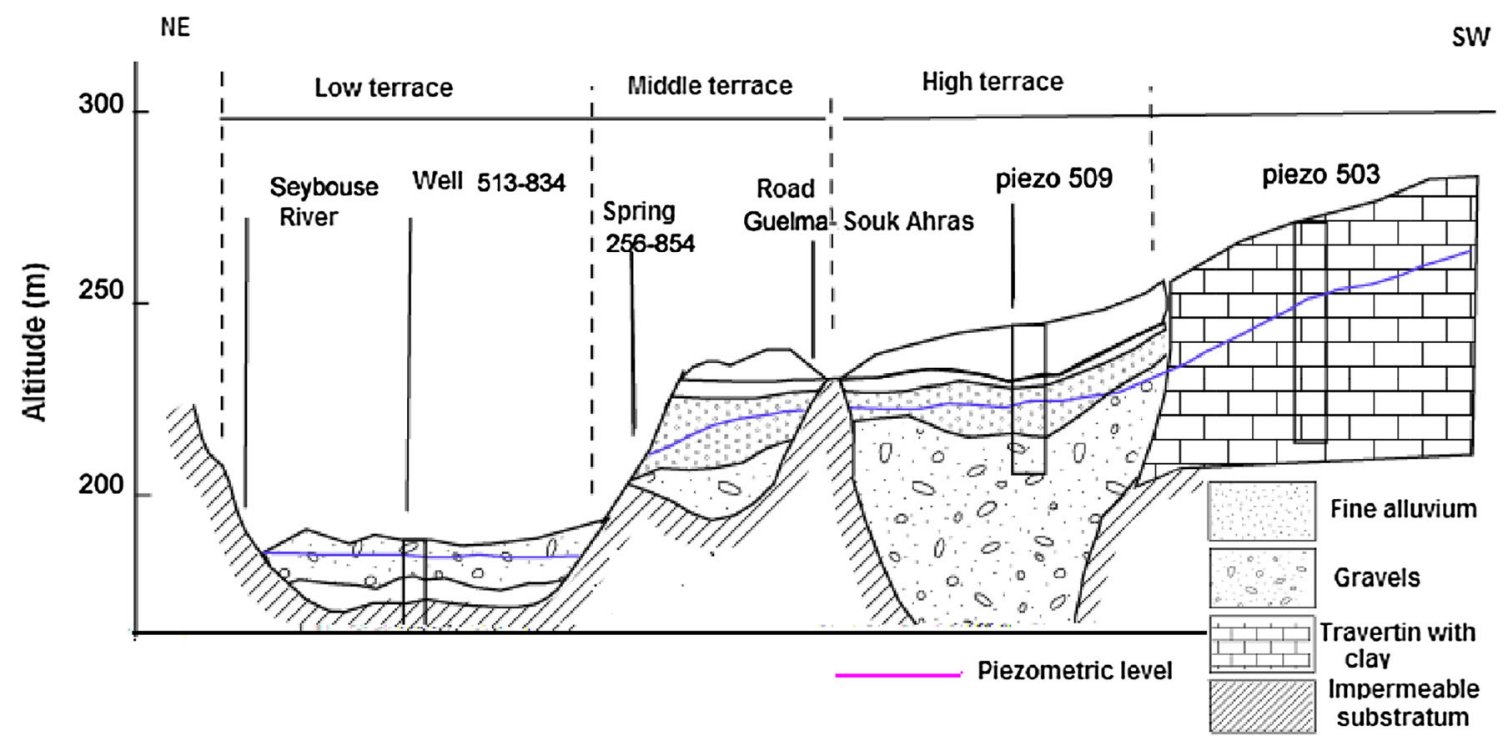

Fig. 2 Geological cross section in study area

were measured in situ using a multi-parameter WTW, and dissolved oxygen was analyzed with device multiline P3PH/LF-SET with a selective probe (WTW). Suspended matter (SM), biochemical oxygen demand $\left(\mathrm{BOD}_{5}\right)$, and chemical oxygen demand (COD) were measured in the laboratory, and the concentration in suspended matter was measured after vacuum filtration using cellulose filters $(0.45 \mu \mathrm{m})$. The $\mathrm{BOD}_{5}$ was measured by the dilution method, and COD was determined by the method of oxidation with potassium bichromate (Rodier 1996). Alkalinity was determined using volumetric titration with sulfuric acid. The cations $\left(\mathrm{Na}^{+}\right.$and $\left.\mathrm{K}^{+}\right)$were carried up by flame spectrophotometric absorption. $\mathrm{Ca}^{++}$and $\mathrm{TH}$ were determined by the titrimetry method using Eriochrome and Murexide as indicators.

A spectrophotometer UV-visible spectral photolab WTW with compatible kits is used to analyze anions $\mathrm{Cl}^{-}, \mathrm{SO}_{4}^{-}$, nutrients $\left(\mathrm{NO}_{2}{ }^{-}, \mathrm{NO}_{3}{ }^{-}, \mathrm{NH}_{4}{ }^{+}\right.$, and $\mathrm{PO}_{4}{ }^{3-}$ ) and metal $\left(\mathrm{Fe}^{3+}\right)$. Analyses have been accomplished at the laboratory of the Algerian Water Agency. To study the water quality for irrigation, sodium adsorption ratio (SAR), the percentage of sodium, and residual sodium carbonate (RSC) were calculated. The results of hydrochemical analysis were compared to WHO standards (2004) standards for the suitability evaluation of the Seybouse Wadi water for drinking and domestic purposes.

In this study, 14 parameters were chosen to calculate the WQI using the standards WHO standards for drinking water. This index enables to know the suitability of water for human consumption (Sahu and Skidar 2008).

The calculation of the WQI index followed 3 steps (Sahu and Sikdar 2008): (a) $w_{i}$ weight is affected to each of the chemical parameters according to its effects on health and its importance in the global quality of water for drinking. The minimum weight 2 is attributed to the parameters considered not dangerous: $\mathrm{Ca}^{2+}, \mathrm{Mg}^{2+}, \mathrm{K}^{+}$. The parameters which have the major effects on water quality have the height weight 5 (Table 1).

(b) The relative weight $\left(W_{i}\right)$ of each parameter is calculated using Eq. 1, and results are presented in Table 1.

$W_{i}=\frac{W_{i}}{\sum_{n=1}^{n} w_{i}}$

(c) The calculation of the rating scale $q i$ for each parameter is obtained by dividing the concentration by its respective standards according the WHO standards' guidelines in each water sample.

The results are multiplied by 100 (Eq. 2).

$q_{i}=\left(\frac{C_{i}}{S_{i}}\right) * 100$

Before computing WQI, the water quality sub-index (SI) is determined for each chemical parameter with the Eq. 3.

$\mathrm{SI}=W_{i} q_{i}$

$\mathrm{WQI}=\sum_{i=1}^{n} \mathrm{SI}_{i}$

\section{Results and discussion}

The samples were collected from 12 different sites from the Seybouse River during four distinct periods, April and 


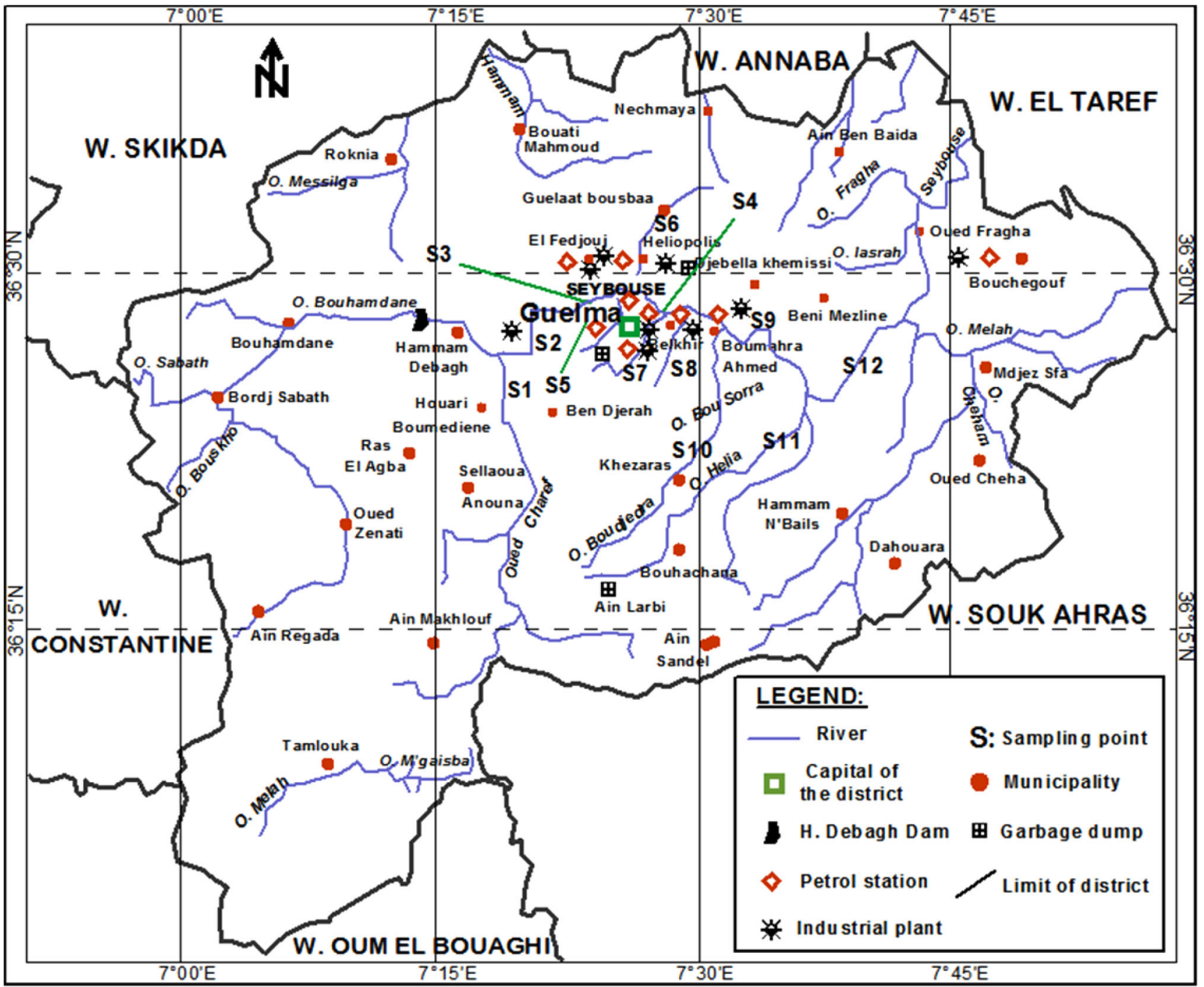

Fig. 3 Sampling points situation

Table 1 The weight and relative weight of each of the physicochemical parameters used for WQI determination

\begin{tabular}{llll}
\hline Parameters & $\begin{array}{l}\text { WHO desirable } \\
\text { limit }(2004)\end{array}$ & $\begin{array}{l}\text { Weight } \\
\left(w_{i}\right)\end{array}$ & $\begin{array}{l}\text { Relative } \\
\text { weight }\left(W_{i}\right)\end{array}$ \\
\hline $\mathrm{pH}$ & 8.5 & 3 & 0.058 \\
$\mathrm{EC}$ & 2,000 & 3 & 0.058 \\
Total dissolved solids (TDS) & 1,000 & 5 & 0.098 \\
Total alkalinity (TA) & 200 & 2 & 0.039 \\
Total hardness (TH) & 300 & 3 & 0.062 \\
Calcium & 200 & 2 & 0.039 \\
Magnesium & 50 & 2 & 0.039 \\
Sodium & 200 & 3 & 0.058 \\
Potassium & 12 & 2 & 0.039 \\
Chloride & 250 & 3 & 0.058 \\
Sulfate & 250 & 3 & 0.058 \\
Nitrate & 50 & 5 & 0.098 \\
Ammonium & 1.5 & 5 & 0.098 \\
Iron & 0.3 & 5 & 0.098 \\
& & $\Sigma w_{i}=51$ & $\Sigma \mathrm{W}_{i}=1.0$ \\
\hline
\end{tabular}

August 2010, January and April 2011. The maximum/ minimum and analytic results for each parameter are summarized in Tables 2 and 3.

The $\mathrm{pH}$ indicates the degree of acidity or alkalinity of water. In this study, $\mathrm{pH}$ did not cross the permissible limit of 6.5-9.5 (WHO standards). The mineralization of water varied with electrical conductivity. The mean value of electrical conductivity was 1,640.5 $\mu \mathrm{s} /$ $\mathrm{cm}$ in El Maiz stream attributed to the intense anthropogenic activities in this part of the basin. The total dissolved solids (TDS) values of Seybouse waters were below the WHO permissible limit $1,000 \mathrm{mg} / \mathrm{l}$. Dissolved oxygen is above the desirable limit of $3 \mathrm{mg} /$ 1 , which denotes that there is no risk for many life forms (Chang 2005).

Biochemical oxygen demand is the quantity of oxygen necessary for the decomposition of organic matter under aerobic conditions (Sawyer and Mc Carty 1978). 
Table 2 Analytical results of the Seybouse Wadi from April 2010 to April 2011

\begin{tabular}{|c|c|c|c|c|c|c|c|c|c|c|c|c|}
\hline Sample & $\mathrm{Ca}^{2+}$ & $\mathrm{Mg}^{2+}$ & $\mathrm{Na}^{+}$ & $\mathrm{K}^{+}$ & $\mathrm{Fe}$ & $\mathrm{HCO}_{3}{ }^{-}$ & $\mathrm{Cl}^{-}$ & $\mathrm{SO}_{4}^{-}$ & $\mathrm{PO}_{4}^{3-}$ & $\mathrm{NO}_{2}{ }^{-}$ & $\mathrm{NO}_{3}{ }^{-}$ & $\mathrm{NH}_{4}^{+}$ \\
\hline \multicolumn{13}{|l|}{ S1 } \\
\hline Mean & 124.42 & 34.81 & 166.75 & 1.15 & 0.17 & 213.62 & 246.94 & 188.55 & 0.10 & 0.05 & 5.77 & 0.19 \\
\hline $\mathrm{SD}$ & 28.51 & 7.16 & 61.68 & 0.26 & 0.13 & 85.65 & 47.97 & 66.07 & 0.07 & 0.03 & 4.85 & 0.18 \\
\hline $\mathrm{CV}$ & 0.23 & 0.21 & 0.37 & 0.23 & 0.73 & 0.40 & 0.19 & 0.35 & 0.68 & 0.61 & 0.84 & 0.96 \\
\hline \multicolumn{13}{|l|}{$\mathrm{S} 2$} \\
\hline Mean & 79.57 & 21.24 & 125.25 & 1.23 & 0.15 & 185.55 & 128.65 & 156.14 & 0.16 & 0.06 & 1.26 & 0.14 \\
\hline SD & 39.31 & 8.28 & 39.05 & 0.38 & 0.21 & 53.62 & 82.30 & 66.26 & 0.31 & 0.05 & 1.27 & 0.08 \\
\hline $\mathrm{CV}$ & 0.49 & 0.39 & 0.31 & 0.31 & 1.41 & 0.29 & 0.64 & 0.42 & 1.93 & 0.87 & 1.01 & 0.53 \\
\hline \multicolumn{13}{|l|}{ S3 } \\
\hline Mean & 87.81 & 27.52 & 148.00 & 1.10 & 0.16 & 192.03 & 157.35 & 187.47 & 0.07 & 0.07 & 6.79 & 0.20 \\
\hline SD & 19.60 & 6.20 & 41.19 & 0.18 & 0.09 & 56.29 & 49.65 & 51.72 & 0.07 & 0.08 & 8.69 & 0.18 \\
\hline $\mathrm{CV}$ & 0.22 & 0.23 & 0.28 & 0.17 & 0.54 & 0.29 & 0.32 & 0.28 & 1.07 & 1.03 & 1.28 & 0.88 \\
\hline \multicolumn{13}{|l|}{ S4 } \\
\hline Mean & 97.21 & 27.87 & 154.50 & 1.38 & 0.11 & 196.06 & 163.33 & 209.13 & 0.26 & 0.08 & 6.38 & 0.22 \\
\hline SD & 23.21 & 7.00 & 40.21 & 0.32 & 0.08 & 62.66 & 48.51 & 56.40 & 0.51 & 0.03 & 6.42 & 0.26 \\
\hline $\mathrm{CV}$ & 0.24 & 0.25 & 0.26 & 0.23 & 0.69 & 0.32 & 0.30 & 0.27 & 1.92 & 0.42 & 1.01 & 1.15 \\
\hline \multicolumn{13}{|l|}{ S5 } \\
\hline Mean & 93.10 & 26.22 & 174.25 & 1.20 & 0.41 & 340.78 & 139.99 & 150.81 & 0.32 & 0.05 & 4.67 & 0.13 \\
\hline $\mathrm{SD}$ & 25.58 & 7.44 & 108.56 & 0.33 & 0.41 & 148.80 & 81.38 & 69.82 & 0.32 & 0.09 & 5.41 & 0.16 \\
\hline $\mathrm{CV}$ & 0.27 & 0.28 & 0.62 & 0.27 & 1.02 & 0.44 & 0.58 & 0.46 & 1.01 & 1.75 & 1.16 & 1.22 \\
\hline \multicolumn{13}{|l|}{ S6 } \\
\hline Mean & 84.67 & 19.76 & 168.50 & 1.25 & 0.12 & 289.15 & 121.36 & 167.79 & 0.07 & 0.17 & 3.89 & 3.12 \\
\hline $\mathrm{SD}$ & 14.13 & 4.66 & 56.20 & 0.29 & 0.08 & 60.37 & 51.57 & 95.04 & 0.09 & 0.14 & 2.09 & 3.16 \\
\hline $\mathrm{CV}$ & 0.17 & 0.24 & 0.33 & 0.23 & 0.68 & 0.21 & 0.42 & 0.57 & 1.34 & 0.82 & 0.54 & 1.01 \\
\hline \multicolumn{13}{|l|}{ S7 } \\
\hline Mean & 112.11 & 19.16 & 209.25 & 1.29 & 0.52 & 331.41 & 153.93 & 210.26 & 0.35 & 0.53 & 21.15 & 0.59 \\
\hline SD & 14.41 & 7.50 & 34.15 & 0.26 & 0.29 & 96.86 & 28.62 & 87.57 & 0.38 & 0.64 & 21.92 & 0.34 \\
\hline $\mathrm{CV}$ & 0.13 & 0.39 & 0.16 & 0.20 & 0.55 & 0.29 & 0.19 & 0.42 & 1.09 & 1.20 & 1.04 & 0.58 \\
\hline \multicolumn{13}{|l|}{ S8 } \\
\hline Mean & 104.51 & 24.69 & 158.75 & 1.27 & 0.32 & 287.93 & 153.54 & 168.19 & 0.17 & 0.43 & 0.85 & 10.65 \\
\hline $\mathrm{SD}$ & 32.48 & 5.87 & 43.02 & 0.30 & 0.23 & 76.30 & 39.83 & 89.21 & 0.20 & 0.82 & 1.02 & 16.18 \\
\hline $\mathrm{CV}$ & 0.31 & 0.24 & 0.27 & 0.23 & 0.74 & 0.27 & 0.26 & 0.53 & 1.18 & 1.89 & 1.20 & 1.52 \\
\hline \multicolumn{13}{|l|}{ S9 } \\
\hline Mean & 93.42 & 34.45 & 167.75 & 1.32 & 0.14 & 255.22 & 129.64 & 252.04 & 0.07 & 0.18 & 0.93 & 1.03 \\
\hline $\mathrm{SD}$ & 23.85 & 13.32 & 44.07 & 0.31 & 0.06 & 84.59 & 51.97 & 93.75 & 0.08 & 0.25 & 0.72 & 1.32 \\
\hline $\mathrm{CV}$ & 0.26 & 0.39 & 0.26 & 0.24 & 0.41 & 0.33 & 0.40 & 0.37 & 1.06 & 1.34 & 0.78 & 1.29 \\
\hline \multicolumn{13}{|l|}{ S10 } \\
\hline Mean & 91.92 & 40.57 & 178.25 & 1.23 & 0.12 & 281.40 & 141.71 & 247.03 & 0.03 & 0.16 & 6.76 & 0.86 \\
\hline SD & 20.16 & 3.42 & 51.84 & 0.26 & 0.03 & 75.89 & 62.84 & 84.80 & 0.03 & 0.13 & 4.98 & 0.53 \\
\hline $\mathrm{CV}$ & 0.22 & 0.08 & 0.29 & 0.21 & 0.30 & 0.27 & 0.44 & 0.34 & 0.95 & 0.79 & 0.74 & 0.62 \\
\hline \multicolumn{13}{|l|}{ S11 } \\
\hline Mean & 109.17 & 34.92 & 150.00 & 1.13 & 0.78 & 215.89 & 150.04 & 252.04 & 2.07 & 0.06 & 2.46 & 1.07 \\
\hline SD & 24.22 & 21.06 & 38.10 & 0.15 & 0.83 & 22.43 & 69.89 & 13.19 & 4.12 & 0.06 & 1.82 & 1.95 \\
\hline $\mathrm{CV}$ & 0.22 & 0.60 & 0.25 & 0.13 & 1.06 & 0.10 & 0.47 & 0.05 & 1.99 & 1.01 & 0.74 & 1.83 \\
\hline \multicolumn{13}{|l|}{$\mathrm{S} 12$} \\
\hline Mean & 99.90 & 32.45 & 168.00 & 1.25 & 0.39 & 237.15 & 177.07 & 206.03 & 0.10 & 0.09 & 4.00 & 0.43 \\
\hline SD & 22.62 & 3.94 & 56.08 & 0.21 & 0.36 & 82.54 & 40.12 & 93.37 & 0.18 & 0.08 & 1.97 & 0.31 \\
\hline $\mathrm{CV}$ & 0.23 & 0.12 & 0.33 & 0.17 & 0.92 & 0.35 & 0.23 & 0.45 & 1.87 & 0.88 & 0.49 & 0.72 \\
\hline
\end{tabular}


Table 3 Analytical results of the Seybouse Wadi from April 2010 to April 2011

\begin{tabular}{|c|c|c|c|c|c|c|c|c|}
\hline Sample & $T\left({ }^{\circ} \mathrm{C}\right)$ & $\mathrm{pH}$ & $\mathrm{EC}(\mu / \mathrm{cm})$ & DO (mg/l) & $\mathrm{SM}(\mathrm{mg} / \mathrm{l})$ & $\begin{array}{l}\mathrm{BOD}_{5} \\
(\mathrm{mg} / \mathrm{l})\end{array}$ & COD (mg/l) & TDS \\
\hline \multicolumn{9}{|l|}{$\mathrm{S} 1$} \\
\hline Mean & 17.00 & 7.63 & $1,210.25$ & 5.03 & 180.63 & 10.73 & 28.64 & 982.50 \\
\hline $\mathrm{SD}$ & 4.24 & 0.30 & 611.99 & 0.69 & 134.98 & 6.86 & 7.56 & 144.53 \\
\hline $\mathrm{CV}$ & 0.25 & 0.04 & 0.51 & 0.14 & 0.75 & 0.64 & 0.26 & 0.15 \\
\hline \multicolumn{9}{|l|}{$\mathrm{S} 2$} \\
\hline Mean & 15.68 & 7.52 & 945.25 & 4.67 & 76.75 & 20.04 & 46.63 & 699.25 \\
\hline SD & 1.73 & 0.38 & 398.12 & 0.96 & 51.12 & 10.87 & 24.80 & 240.87 \\
\hline $\mathrm{CV}$ & 0.11 & 0.05 & 0.42 & 0.21 & 0.67 & 0.54 & 0.53 & 0.34 \\
\hline \multicolumn{9}{|l|}{ S3 } \\
\hline Mean & 16.33 & 7.63 & $1,192.00$ & 4.94 & 162.55 & 33.11 & 84.30 & 808.25 \\
\hline SD & 2.65 & 0.17 & 393.87 & 0.54 & 118.50 & 24.91 & 66.23 & 178.53 \\
\hline $\mathrm{CV}$ & 0.16 & 0.02 & 0.33 & 0.11 & 0.73 & 0.75 & 0.79 & 0.22 \\
\hline \multicolumn{9}{|l|}{$\mathrm{S} 4$} \\
\hline Mean & 19.05 & 7.48 & $1,254.50$ & 4.06 & 102.38 & 9.97 & 25.92 & 856.25 \\
\hline $\mathrm{SD}$ & 3.89 & 0.62 & 399.17 & 0.53 & 68.73 & 11.81 & 16.50 & 185.36 \\
\hline $\mathrm{CV}$ & 0.20 & 0.08 & 0.32 & 0.13 & 0.67 & 1.18 & 0.64 & 0.22 \\
\hline \multicolumn{9}{|l|}{ S5 } \\
\hline Mean & 20.08 & 7.58 & $1,311.50$ & 3.72 & 85.28 & 82.41 & 170.74 & 931.75 \\
\hline $\mathrm{SD}$ & 3.65 & 0.22 & 611.69 & 1.07 & 52.62 & 131.27 & 258.15 & 391.48 \\
\hline $\mathrm{CV}$ & 0.18 & 0.03 & 0.47 & 0.29 & 0.62 & 1.59 & 1.51 & 0.42 \\
\hline \multicolumn{9}{|l|}{ S6 } \\
\hline Mean & 19.80 & 7.39 & 998.25 & 2.54 & 123.88 & 16.70 & 58.15 & 856.75 \\
\hline $\mathrm{SD}$ & 2.94 & 0.47 & 157.54 & 0.99 & 85.65 & 16.24 & 21.76 & 106.80 \\
\hline $\mathrm{CV}$ & 0.15 & 0.06 & 0.16 & 0.39 & 0.69 & 0.97 & 0.37 & 0.12 \\
\hline \multicolumn{9}{|l|}{ S7 } \\
\hline Mean & 20.48 & 7.26 & $1,640.50$ & 2.16 & 141.63 & 219.55 & 546.80 & $1,052.75$ \\
\hline SD & 3.18 & 0.40 & 253.33 & 1.82 & 158.10 & 116.40 & 352.10 & 124.67 \\
\hline $\mathrm{CV}$ & 0.16 & 0.06 & 0.15 & 0.85 & 1.12 & 0.53 & 0.64 & 0.12 \\
\hline \multicolumn{9}{|l|}{ S8 } \\
\hline Mean & 20.85 & 7.32 & $1,236.00$ & 2.20 & 161.13 & 37.14 & 220.20 & 900.75 \\
\hline SD & 3.85 & 0.32 & 119.10 & 0.98 & 43.39 & 44.73 & 117.90 & 119.17 \\
\hline $\mathrm{CV}$ & 0.18 & 0.04 & 0.10 & 0.45 & 0.27 & 1.20 & 0.54 & 0.13 \\
\hline \multicolumn{9}{|l|}{ S9 } \\
\hline Mean & 20.08 & 7.14 & $1,314.50$ & 3.13 & 63.00 & 16.04 & 57.42 & 935.25 \\
\hline SD & 2.69 & 0.53 & 281.17 & 1.13 & 73.76 & 14.82 & 47.74 & 161.76 \\
\hline $\mathrm{CV}$ & 0.13 & 0.07 & 0.21 & 0.36 & 1.17 & 0.92 & 0.83 & 0.17 \\
\hline \multicolumn{9}{|l|}{$\mathrm{S} 10$} \\
\hline Mean & 20.23 & 7.82 & $1,355.00$ & 3.84 & 213.16 & 50.39 & 80.78 & 989.00 \\
\hline SD & 5.22 & 0.51 & 259.45 & 0.98 & 222.44 & 61.98 & 73.43 & 185.97 \\
\hline $\mathrm{CV}$ & 0.26 & 0.07 & 0.19 & 0.26 & 1.04 & 1.23 & 0.91 & 0.19 \\
\hline \multicolumn{9}{|l|}{ S11 } \\
\hline Mean & 21.18 & 7.61 & $1,164.25$ & 3.74 & 91.59 & 52.58 & 174.02 & 918.25 \\
\hline SD & 4.38 & 0.88 & 287.35 & 0.94 & 57.69 & 35.73 & 211.29 & 122.98 \\
\hline $\mathrm{CV}$ & 0.21 & 0.11 & 0.25 & 0.25 & 0.63 & 0.68 & 1.21 & 0.13 \\
\hline \multicolumn{9}{|l|}{ S12 } \\
\hline Mean & 21.88 & 7.56 & $1,472.50$ & 3.47 & 136.50 & 53.38 & 97.58 & 926.25 \\
\hline SD & 5.12 & 0.57 & 359.95 & 0.97 & 137.57 & 42.09 & 52.65 & 142.99 \\
\hline $\mathrm{CV}$ & 0.23 & 0.08 & 0.24 & 0.28 & 1.01 & 0.79 & 0.54 & 0.15 \\
\hline
\end{tabular}



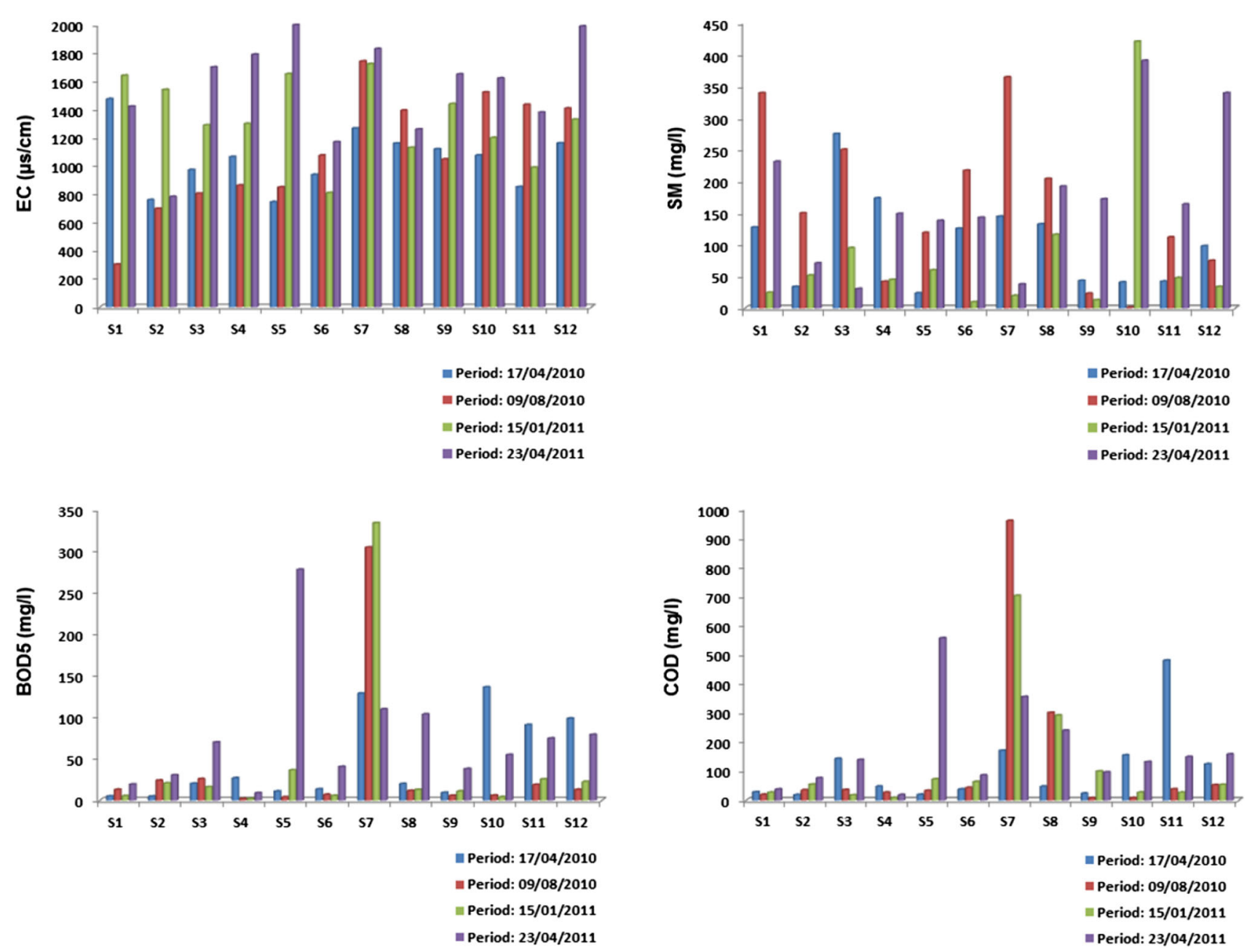

Fig. 4 Variations of electrical conductivity, suspended matter, $\mathrm{BOD}_{5}$, and $\mathrm{COD}$

According to $\mathrm{WHO}$ standards, $\mathrm{BOD}_{5}$ did not exceed $6 \mathrm{mg} /$ 1. $\mathrm{BOD}_{5}$ concentration ranged from $219.55 \pm 116.4 \mathrm{mg} / \mathrm{l}$ in station 7 (EL Maiz Stream) to $9.97 \pm 11.81 \mathrm{mg} / \mathrm{l}$ in the station 4 (Heliopolis).

The COD determines the oxygen required for inorganic substances. The chemical oxidation of most organic matter and oxidizable inorganic substances COD determine the quantity of organic pollutant found in water. COD values in Oued El Maiz station (S7) were $540.80 \pm 352.10 \mathrm{mg} / \mathrm{l}$, and were $25.92 \pm 16.50 \mathrm{mg} / \mathrm{l}$ in Heliopolis station (S4) (Fig. 4).

The $\mathrm{BOD}_{5}$ and COD are indirect measurements of dissolved oxygen quantity in water and represent the amount of organic compounds in water. This load is the result of the urban and industrial waste which volume varies according to the density of population, the nature, and the importance of industries. A classification of hardness degree is given in terms of its $\mathrm{CaCO}_{3 \text { equivalent }}$ concentration (Table 4), and accordingly, the Seybouse water belongs to soft and medium category (Sawyer and Mc Carty 1978).
Table 4 Classification of water depending upon the Hardness (WHO 2004)

\begin{tabular}{ll}
\hline Classification & Hardness range $(\mathrm{mg} / \mathrm{l})$ \\
\hline Soft & $0-75$ \\
Medium hard & $75-150$ \\
Hard & $150-300$ \\
Very hard & Above 300 \\
\hline
\end{tabular}

Hydrochemistry

The tendency of the cations in all stations of the Seybouse River are in the order of $\mathrm{Na}^{+} \mathrm{Ca}^{2+}>\mathrm{Mg}^{2+}>\mathrm{K}^{+}$with sodium as a dominant cation and the tendency of anions is in the order of $\mathrm{Cl}^{-}>\mathrm{SO}_{4}{ }^{2-}>\mathrm{HCO}_{3}{ }^{-}$, with chloride as the dominant anion. In contrast to this, the predominant anion trend is in the order $\mathrm{HCO}_{3}{ }^{-}>\mathrm{Cl}^{-}>\mathrm{SO}_{4}{ }^{2-}$ in the station $\mathrm{S} 5$ and $\mathrm{S} 8$, whereas the order in the stations $\mathrm{S} 6, \mathrm{~S} 7$, $\mathrm{S} 9$, and $\mathrm{S} 10$ is $\mathrm{HCO}_{3}{ }^{-}, \mathrm{SO}_{4}{ }^{2-}, \mathrm{Cl}^{-}$with bicarbonate as the dominant anion (Figs. 5, 6).

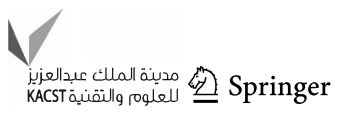



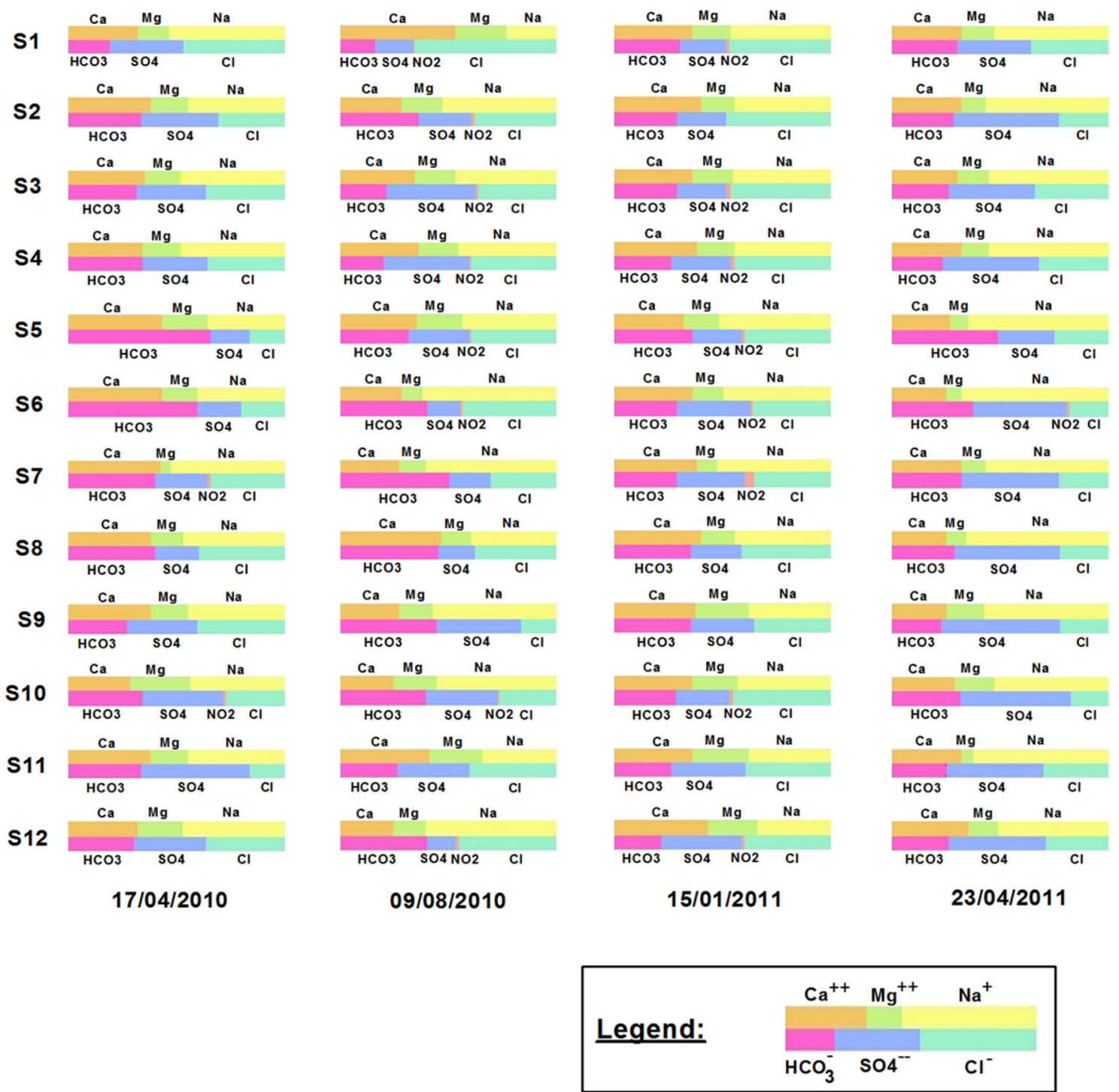

Fig. 5 Stabler diagram illustrating major ionic dominance in the surface water of the Seybouse River

Variation of cations

The calcium concentration is about $124.42 \pm 28.50 \mathrm{mg} / \mathrm{l}$ (station 1), $87.80 \pm 19.59 \mathrm{mg} / \mathrm{l}$ (station 3), and $99.89 \pm$ $22.50 \mathrm{mg} / \mathrm{l}$ (station 12). It is apparent that station 1 showed higher calcium content compared to the other stations. However, calcium in water did not exceed the permissible limit of $200 \mathrm{mg} / \mathrm{l}$. The mean magnesium concentration is $40.56 \pm 3.41 \mathrm{mg} / \mathrm{l}$ (station 10) and $19.16 \pm 7.50 \mathrm{mg} / \mathrm{l}$ (station 7). It is evident that the Seybouse water had a magnesium concentration within the permissible limit of $100 \mathrm{mg} / \mathrm{l}$. The mean sodium concentration is $209.25 \pm 34.15 \mathrm{mg} / \mathrm{l}$ (station 7). The mean sodium value in station 3 is $148 \pm 41.19 \mathrm{mg} / \mathrm{l}$. It is apparent that the water of the Seybouse River showed generally sodium values within the permissible limit of $200 \mathrm{mg} / \mathrm{l}$. The mean potassium concentration is $1.1 \pm 0.18 \mathrm{mg} / \mathrm{l}$ (station 3); in station 7 water indicates a low concentration of potassium (1.29 \pm $0.26 \mathrm{mg} / \mathrm{l}$ ) compared to the permissible limit of $10 \mathrm{mg} / \mathrm{l}$ (WHO standards). The mean ferrous iron $\left(\mathrm{Fe}^{2+}\right)$ value is $0.77 \pm 0.82 \mathrm{mg} / \mathrm{l}$ (station 11), $0.11 \pm 0.07 \mathrm{mg} / \mathrm{l}$ (station 4), ferrous iron concentration is under the permissible limit of $1.0 \mathrm{mg} / \mathrm{l}$ (WHO standards).

Variation of anions

The mean bicarbonate value is $55 \pm 56.29 \mathrm{mg} / \mathrm{l}$ (station 2) and $340.77 \pm 148.79 \mathrm{mg} / \mathrm{l}$ (station 5). The average chloride concentration in the Seybouse River is $246.93 \pm 47.96 \mathrm{mg} /$ 1 (station 1) and $121.36 \pm 51.57 \mathrm{mg} / \mathrm{l}$ (station 6). Higher 
Fig. 6 Piper diagram of surface water of the Seybouse River

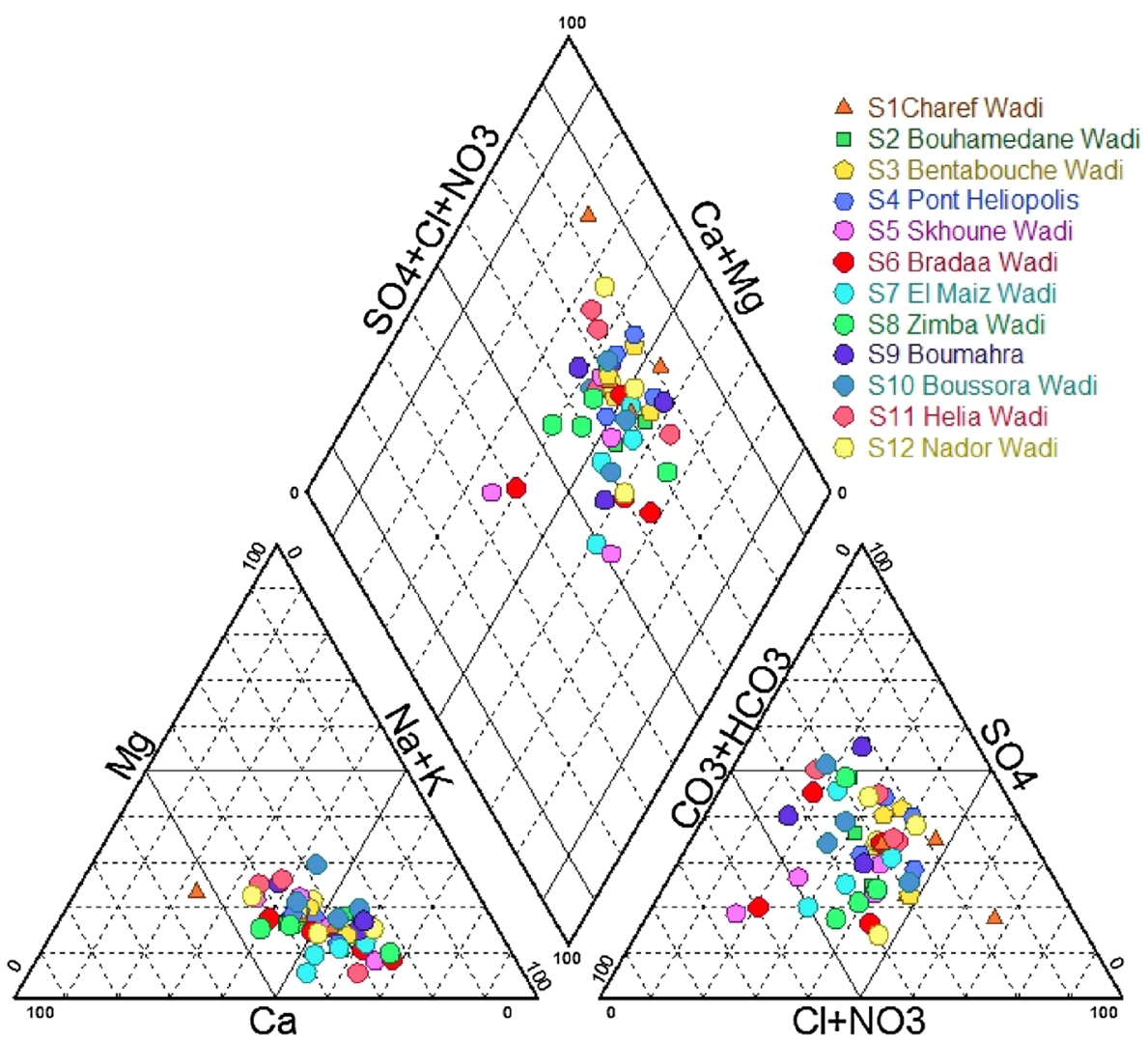

chloride values are recorded in the station of Charef compared to the other stations where chloride values are below the permissible limit of $250 \mathrm{mg} / \mathrm{l}$. The mean sulfate concentration is $252.03 \pm 13.19 \mathrm{mg} / \mathrm{l}$ (station 12 of the Helia stream), $150.80 \pm 69.81 \mathrm{mg} / \mathrm{l}$ (station 5) showing sulfate values under the permissible limit of $400 \mathrm{mg} / \mathrm{l}$.

The mean nitrate concentration is $21.14 \pm 21.19 \mathrm{mg} / \mathrm{l}$ (station 7) and $1.26 \pm 1.01 \mathrm{mg} / \mathrm{l}$ (station 2). The Seybouse water showed nitrate values under the permissible limit of $50 \mathrm{mg} / \mathrm{l}$ (Fig. 7). The high concentration of nitrates in surface water and groundwater are the result of intensive agricultural activity or a contamination by human or animal wastes (Nas and Berktay 2006).

The mean concentration of phosphate in the station 11 (Helia stream) is $2.06 \pm 4.412 \mathrm{mg} / \mathrm{l}$. It exceeds the permissible limit of $0.3 \mathrm{mg} / \mathrm{l}$, and hence, the risk of eutrophication is not excluded in this part of the River favored by the domestic wastewater (Vyas et al. 2006).

The major part of watershed is overlain by a Miocene and Pliocene to Quaternary cover of sand, gravel, and alluvium. The Triassic formation intruded the sedimentary cover as diapir and consists of evaporitic formations composed of gypsum-bearing marl, shale, dolomite, limestone, and salt, which explains the prevalence of sodium and chloride facies in the majority of samples. The autochthonous Neritic formation of Cretaceous age, composed mainly of a thick and massive limestone with karstic features and the Tellian formation composed of cretaceous marl and limestone, may explain the origin of bicarbonates dominant in the stations S6, S7, S9 and S10.

Water aptitude for irrigation

Sodium adsorption ratio

Water is excellent for irrigation purposes if the SAR is under 10. The SAR values are calculated according to the following Eq. 5:

$\mathrm{SAR}=\frac{\mathrm{Na}^{+}}{\sqrt{\frac{\mathrm{Ca}^{2+}+\mathrm{Mg}^{2+}}{2}}}$

The concentration of $\mathrm{Ca}^{2+}, \mathrm{Mg}^{2+}$ and $\mathrm{Na}^{+}$are in $\mathrm{meq} / 1$

The calculated value of SAR in the study area ranges from 1.44 to 6.94 (Table 5) in Seybouse River. There is a significant relationship between SAR values of irrigation water and the extent to which sodium is adsorbed by the soils. If water used for irrigation is high in sodium and low in calcium, the cationexchange complex may become saturated with sodium. This can destroy the soil structure owing to dispersion of the clay particles. According to SAR values; suitability of water for irrigation is summarized in Table 6. 

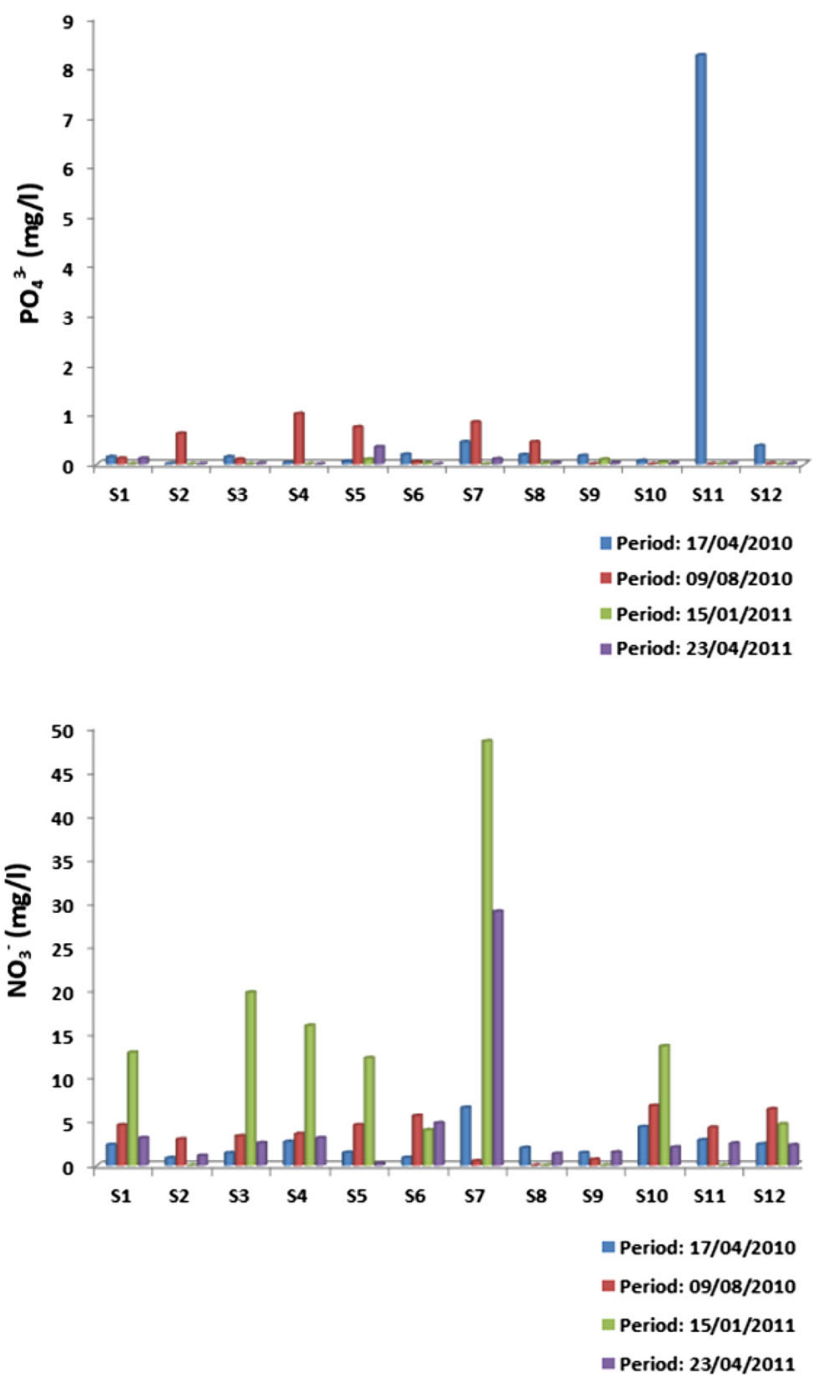

Fig. 7 Variations of nitrate, nitrite, ammonium, and orthophosphates

\section{Residual sodium carbonate}

The high concentration of bicarbonate ions in water provokes the precipitation of calcium and magnesium as carbonates and then the proportion of sodium in the soil increases. The RSC is calculated using the following equation:

$\mathrm{RSC}=($ Alkalinity $\times 0.0333)-\left(\mathrm{Ca}^{2+}+\mathrm{Mg}^{2+}\right)$

The concentration of $\mathrm{Ca}^{2+}$ and $\mathrm{Mg}^{2+}$ are in meq/l and alkalinity values in $\mathrm{mg} / \mathrm{l}$ (Table 5 ).

Irrigation water having RSC values greater than $5 \mathrm{meq} / \mathrm{l}$ have been considered harmful to the growth of plants, while waters with RSC values above $2.5 \mathrm{meq} / \mathrm{l}$ are unsuitable for irrigation. An RSC value between 1.25 and $2.5 \mathrm{meq} / \mathrm{l}$ is considered as the marginal quality and value $<1.25 \mathrm{meq} / \mathrm{l}$ as the safe limit for irrigation (Table 7). The calculated
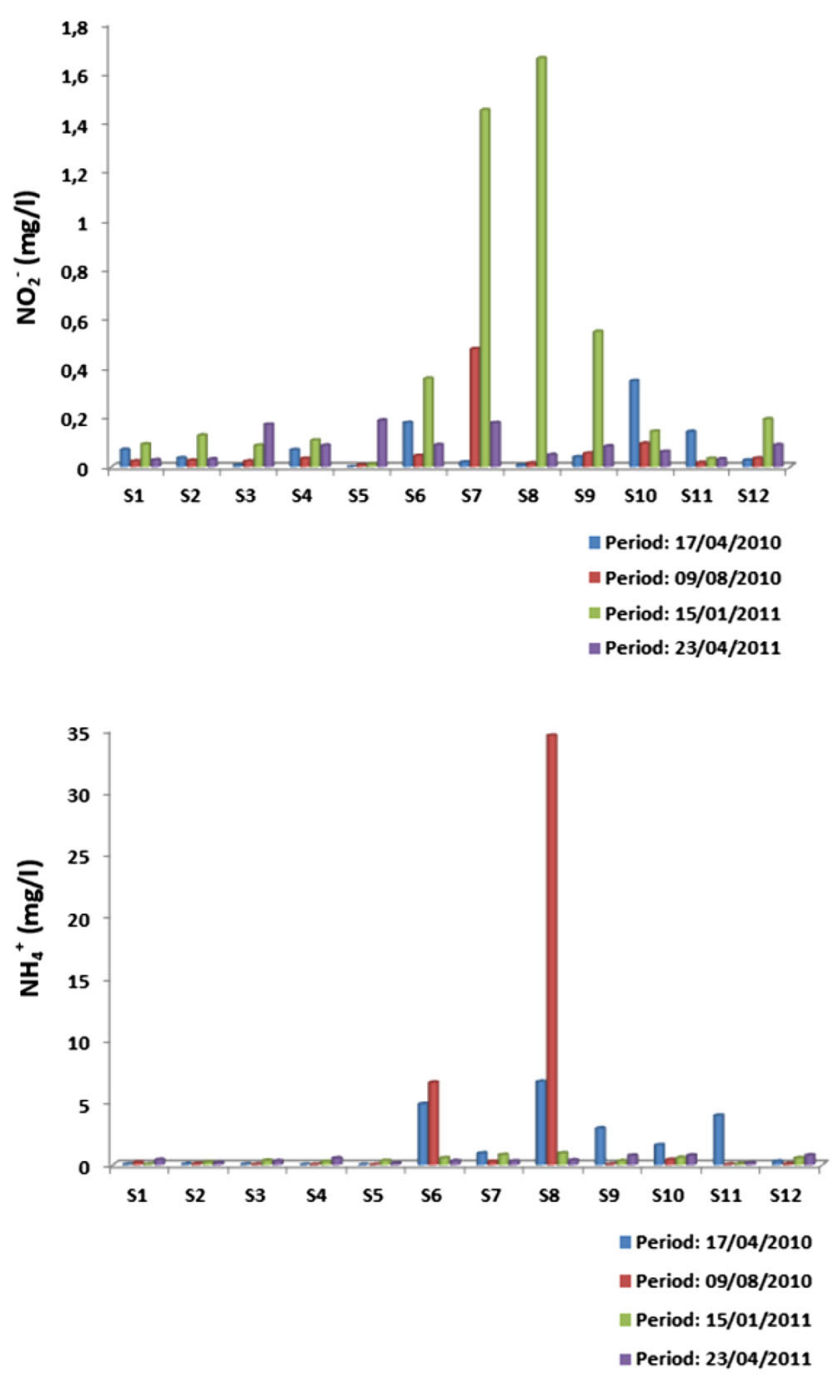

RSC values in the groundwater samples of Seybouse River are found to vary from -9.60 to $1.60 \mathrm{meq} / \mathrm{l}$ (Table 5).

\section{Percent sodium}

$\mathrm{Na}^{+}$is an important cation which in excess deteriorates the soil structure and reduces crop yield (Ayers and Westcot 1985). When the concentration of $\mathrm{Na}^{+}$is high in irrigation water, $\mathrm{Na}^{+}$tends to be absorbed by clay particles displacing $\mathrm{Mg}^{2+}$ and $\mathrm{Ca}^{2+}$ ions. This exchange process of $\mathrm{Na}^{+}$in water for $\mathrm{Ca}^{2+}$ and $\mathrm{Mg}^{2+}$ in soil reduces the permeability and eventually results in soil with poor internal drainage. The $\mathrm{Na} \%$ is calculated using the formula given below according to Wilcox classification. The high percentage of sodium in the irrigation water has dangerous effects on soil. This percentage should not exceed 60 (Wilcox 1955) (Table 8). 
Table 5 Results of the calculations of SAR, RSC, and \% Na

\begin{tabular}{lcrlllll}
\hline Sample & SAR & RSC & \% Na & Sample & SAR & RSC & $\%$ Na \\
\hline S1 & 4.25 & -4.36 & 53.48 & S7 & 4.01 & -1.51 & 52.95 \\
S1 & 1.44 & -9.47 & 22.98 & S7 & 5.75 & 0.93 & 60.69 \\
S1 & 3.64 & -4.81 & 45.55 & S7 & 4.44 & -3.83 & 52.25 \\
S1 & 4.71 & -3.84 & 52.95 & S7 & 4.99 & -2.66 & 56.21 \\
S2 & 2.49 & -2.32 & 44.09 & S8 & 2.95 & -2.30 & 44.98 \\
S2 & 3.07 & -1.17 & 53.34 & S8 & 2.86 & -3.19 & 39.22 \\
S2 & 3.33 & -5.19 & 43.15 & S8 & 3.18 & -3.61 & 44.09 \\
S2 & 4.13 & -2.15 & 56.52 & S8 & 6.16 & -1.15 & 66.23 \\
S3 & 3.17 & -2.78 & 47.93 & S9 & 2.78 & -3.67 & 43.42 \\
S3 & 2.80 & -3.51 & 45.89 & S9 & 4.71 & -0.51 & 57.57 \\
S3 & 3.37 & -4.67 & 44.53 & S9 & 2.83 & -5.59 & 37.67 \\
S3 & 4.73 & -3.19 & 56.23 & S9 & 5.11 & -3.66 & 57.90 \\
S4 & 3.52 & -2.78 & 48.65 & S10 & 2.76 & -3.22 & 42.77 \\
S4 & 2.68 & -3.71 & 44.52 & S10 & 5.08 & -1.77 & 55.64 \\
S4 & 3.35 & -5.68 & 43.40 & S10 & 3.21 & -5.14 & 42.82 \\
S4 & 4.64 & -3.71 & 55.38 & S10 & 4.44 & -3.32 & 52.74 \\
S5 & 1.79 & -0.61 & 35.09 & S11 & 2.83 & -3.23 & 43.70 \\
S5 & 2.58 & -2.98 & 42.91 & S11 & 2.45 & -7.43 & 33.99 \\
S5 & 4.66 & -3.03 & 52.18 & S11 & 2.74 & -6.48 & 37.55 \\
S5 & 6.94 & 1.60 & 64.80 & S11 & 5.48 & -2.18 & 62.60 \\
S6 & 2.40 & -0.78 & 39.49 & S12 & 3.18 & -3.54 & 46.06 \\
S6 & 5.00 & -0.41 & 61.08 & S12 & 5.55 & -0.69 & 60.69 \\
S6 & 3.62 & -3.42 & 49.13 & S12 & 2.18 & -6.58 & 33.79 \\
S6 & 6.58 & 0.06 & 67.69 & S12 & 4.26 & -4.43 & 50.79 \\
\hline & & & & & & &
\end{tabular}

Table 6 Classification of irrigation water based on SAR

\begin{tabular}{|c|c|c|c|}
\hline $\begin{array}{l}\text { SI } \\
\text { No }\end{array}$ & $\begin{array}{l}\text { Types of water and } \\
\text { SAR value }\end{array}$ & Quality & Suitability for irrigation \\
\hline 1 & $\begin{array}{l}\text { Low sodium water } \\
\text { (S1) SAR value: } \\
0-10\end{array}$ & Excellent & $\begin{array}{l}\text { Suitable for all types of crops } \\
\text { and all types of soils, except } \\
\text { for those crops, which are } \\
\text { sensitive to sodium }\end{array}$ \\
\hline 2 & $\begin{array}{l}\text { Medium sodium water } \\
\text { (S2) SAR value: } \\
\text { 10-18 }\end{array}$ & Good & $\begin{array}{l}\text { Suitable for coarse textured } \\
\text { or organic soil with good } \\
\text { permeability. Relatively } \\
\text { unsuitable in fine textured } \\
\text { soils }\end{array}$ \\
\hline 3 & $\begin{array}{l}\text { High sodium water } \\
\text { (S3) SAR value: } \\
\text { 18-26 }\end{array}$ & Fair & $\begin{array}{l}\text { Harmful for almost all types } \\
\text { of soil; requires good } \\
\text { drainage, high leaching } \\
\text { gypsum addition }\end{array}$ \\
\hline 4 & $\begin{array}{l}\text { Very high sodium } \\
\text { water (S4) SAR } \\
\text { value: above } 26\end{array}$ & Poor & Unsuitable for irrigation \\
\hline
\end{tabular}

The percentage of sodium can be determined using the following formula:

$\% \mathrm{Na}=\frac{\mathrm{Na}^{+}}{\left(\mathrm{Ca}^{2+}+\mathrm{Mg}^{2+}+\mathrm{K}^{+}+\mathrm{Na}^{+}\right)} \times 100$
Table 7 Water quality based on RSC (Richards 1954)

\begin{tabular}{ll}
\hline RSC (epm) & Remark on quality \\
\hline$<1.25$ & Safe/good \\
$1.25-2.50$ & Marginal/doubtful \\
$>2.50$ & Unsuitable \\
\hline
\end{tabular}

Table 8 Sodium percent water class (Wilcox 1955)

\begin{tabular}{ll}
\hline Sodium $(\%)$ & Water class \\
\hline$<20$ & Excellent \\
$20-40$ & Good \\
$40-60$ & Permissible \\
$60-80$ & Doubtful \\
$>80$ & Unsuitable \\
\hline
\end{tabular}

The concentration of $\mathrm{Ca}^{2+}, \mathrm{Mg}^{2+}, \mathrm{Na}^{+}$, and $\mathrm{K}^{+}$are expressed in meq/l.

The mean percent sodium concentration in all samples belongs to the permissible category (Table 8 ; Fig. 8). The calculated values of SAR, RSC, and \% Na reveal that all the sampling sites are good for irrigation purpose except few, particularly the stations S5, S8 and S11.

Water quality index

The computed WQI values are classified into five types namely, excellent water $(0<\mathrm{WQI}<25)$, good water $(25<\mathrm{WQI}<50)$, poor water $(50<\mathrm{WQI}<75)$, very poor water $(75<\mathrm{WQI}<100)$, and water unsuitable for drinking (WQI $>100$ ) (Brown et al. 1970). In this study, the calculated WQI value in station 2 is 42.44 and 49.86 in station 3. The results indicate that the Seybouse Wadi water coincides with the poor water class category except for the water of Bouhamdan stream (station 2) and station 3 of Bentabouche (Table 9). Agricultural and industrial activities present in the study area developed several forms of surface water pollution. The population in of Guelma increased during two decades from 77,821 to 157,334 inhabitants, sewage of agglomerations is discharged directly in the Seybouse River without preliminary treatment (Djabri et al. 2003). In the region of Guelma, ceramic and agro industry factories discharge waste waters in the Seybouse River, other sources of pollution come from petrol stations distributed throughout the region. Nitrogen fertilizers are largely used, large amounts of nitrogen comes from farms can cause a surface water pollution.

Three industrial areas situated, respectively, upstream Oued Zimba and in the left banks of Oued El Maiz and the Seybouse River. The investigations established by the environmental service indicate the presence of dozens of 
Fig. 8 Wilcox diagram of surface water of the Seybouse River

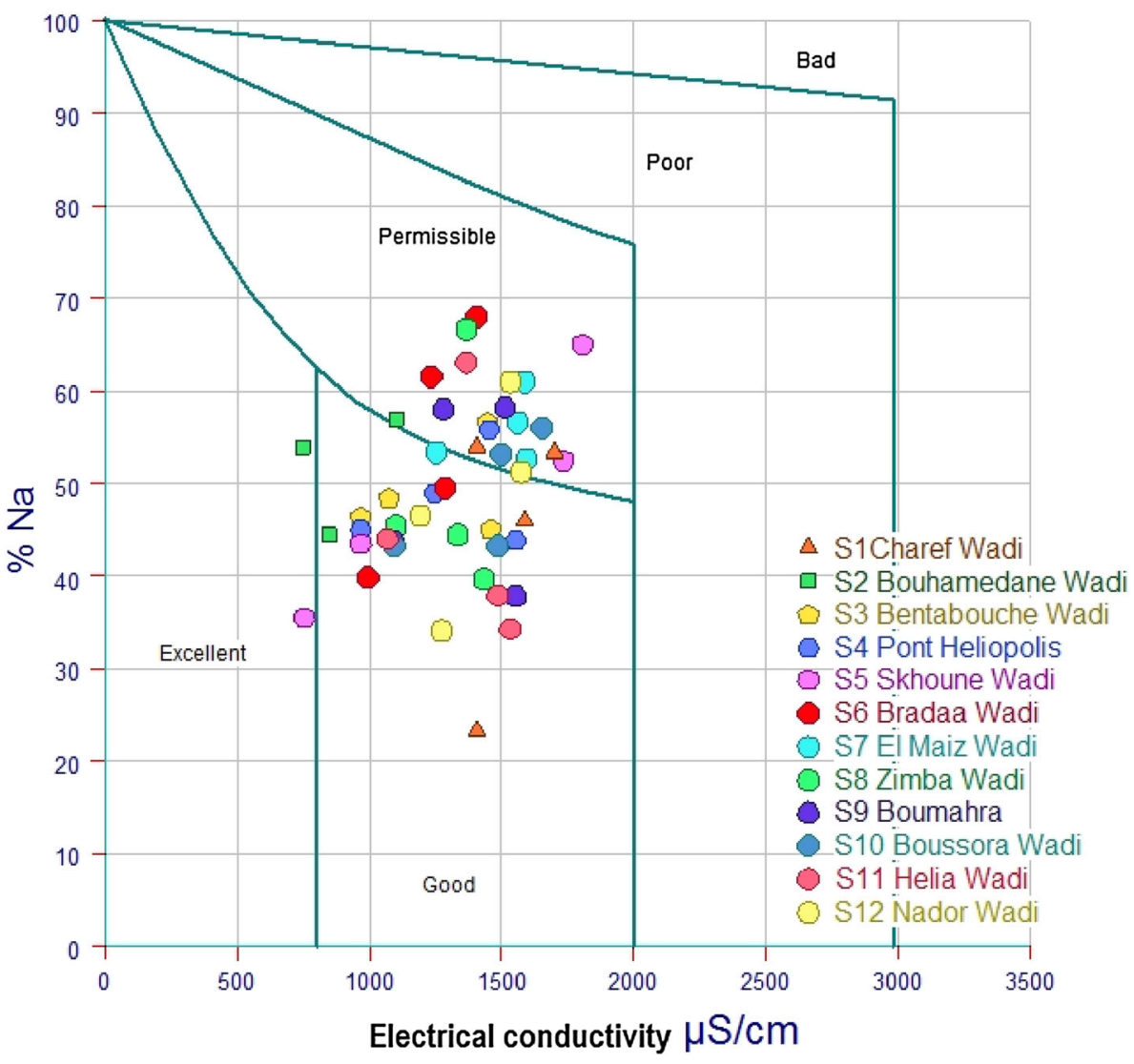

Table 9 Water quality index of surface water

\begin{tabular}{lr}
\hline Sample & WQI \\
\hline S1 & 56.14 \\
S2 & 42.44 \\
S3 & 49.87 \\
S4 & 50.47 \\
S5 & 60.12 \\
S6 & 71.83 \\
S7 & 98.32 \\
S8 & 142.72 \\
S9 & 63.79 \\
S10 & 64.69 \\
S11 & 64.94 \\
S12 & 64.50 \\
\hline
\end{tabular}

petrol stations, industrial plants of sugar, ceramic, brick, and marble discharges their effluents into Seybouse River tributaries (Zimba, Skoune, Maiz, and Boussoura) (Mouchara 2009). This explains the high WQI values obtained in these stations. Around Bentabouche and Bouhamedane stations, there are no large-scale industries, and a low population is unregistered in this sector; in addition, an important quantity of water that is dropped from Bouhamdane dam have the effect of decreasing the pollutants from surface water by dilution. This may explain the low WQI values unregistered in the two stations.

\section{Conclusion}

The present study dealt with the control of the water of the Seybouse River during a period of 4 months. According to the criteria of appreciation of the surface water quality, this river can be classified as not being extremely polluted. The high WQI values in water were mainly due to the presence of major chemical elements and nutrients. The other parameters (BOD, COD, and suspended matter) were high and reached 200, 500 and $200 \mathrm{mg} / \mathrm{l}$, respectively. The spatial variation highlighted two distinct zones: the downstream presented a pollutant load almost twice higher than in the upstream zone, and this was directly related to anthropogenic factors; such as the importance of the discharge of urban and industrial waste. Compared with other rivers on a global scale, the Seybouse River is not very polluted. Further studies on the scale of the watershed of the Seybouse will be necessary to evaluate the effect of water on the land use, socio-economic development, and hydro-climatic factors on the surface water quality. In Algeria or even in Africa, there is no specific index of evaluation of the quality of surface water. Therefore, 
developing models like the WQI are necessary for an effective and quick control of the water quality and for an easier communication of results to the mangers of water resources.

Open Access This article is distributed under the terms of the Creative Commons Attribution License which permits any use, distribution, and reproduction in any medium, provided the original author(s) and the source are credited.

\section{References}

Ayers RS, Westcot DW (1985) Water quality for agriculture. FAO of the United Nations, paper 29, Rev.1, Rome, Italy

Bordalo A, Teixeira R, Wiebe JW (2006) A water quality index applied to an international shared river basin: the case of the Douro River. Environ Manage 38:910-920

Brown RM, McClelland NI, Deininger RA, Tozer RG (1970) A water quality index-do we dare? Water Sew Wks, pp 339-343

Canadian Council of Ministries of the Environment (CCMC) (2001) Canadian Water Quality Index 1.0 Technical Report and User's Manual, Canadian Environmental Quality Guidelines, Technical Subcommittee, Gatineau

Canter LW (1996) Environmental Impact Assessment, 2nd edn. McGraw-Hill Inc, New York

Chang H (2005) Spatial and temporal variation of water quality in the Han River and its tributaries, Seoul, Korea, 1993-2002. Water Air Soil Pollut 161:267-284

Djabri L, Hani A, Laouar R, Mania J, Mudry J, Louhi A (2003) Potential pollution of groundwater in the valley of the Seybouse River, north-eastern Algeria. Environ Geol 44(6):738-774

Dojlido JR, Best GA (1993) Chemistry of water and water pollution. Ellis Horwood, London

Gold ZG, Glushchenko LA, Morozova SP, Shulepina SP, Shadrin I (2003) A water quality assessment based on chemical and biological characteristics: an example of classification of characteristics for the Cheremushnyi Creek-Yenisey River water system. Russia Water Resour 30:304-314

Horton RK (1965) An index number system for rating water quality. J Water Pollut Control Fed 37(3):300-306
Mouchara N (2009) Impact of the Hammam Debagh Dam on the water quality of the Seybouse valley in the upstream part. Master thesis, Badji Mokhtar Annaba University

Zali MA, Retnam A,Juahir H, Zain SM , Kasim MF, Abdullah B, Saadudin SB (2011) Sensitivity analysis for water quality index (WQI) prediction for Kinta River, Malaysia, World Appl Sci J $60-65$

Nas B, Berktay A (2006) Groundwater contamination by nitrates in the city of Konya (Turkey): a GIS perspective. J Environ Manage 79:30-37

Nives SG (1999) Water quality evaluation by index in Dalmatia. Croatia Water Res 33:3423-3440

Richards L.A (U.S. Salinity Laboratory) (1954) Diagnosis and improvement of saline and alkaline soils, US Department of Agriculture Hand Book

Rodier J (1996) Analysis of water. Edition Dunod, Paris in French

Sahu P, Sikdar PK (2008) Hydrochemical framework of the aquifer in and around East Kolkata Wetlands. West Bengal India Environ Geol 55:823-835

Said A, Stevens DK, Sehlke G (2004) An innovative index for evaluating water quality in streams, Idaho, USA. Environ Manag 34:406-414

Sawyer CN, McCarty PL (1978) Chemistry for environmental engineering, 3rd edn. McGraw-Hill Book Company, New York

Susilo GE, Febrina R (2011) The simplification of DOE water quality index calculation procedures using graphical analysis. Aust $\mathrm{J}$ Basic Appl Sci 5(2):207-214

Tiwari TN, Mishra M (1985) A preliminary assignment of water quality index of major Indian rivers. Indian $\mathrm{J}$ Environ Prot 5(4):276-279

Vila JM (1980) The Alpine range of Eastern Algerian and the borders Algerian-Tunisian. Es Sciences Thesis. University of Pierre and Marie Curie, Paris VI, pp 282-296 (in French)

Vyas A, Mishra DD, Bajapai A, Dixit S, Verma N (2006) Environment impact of idol immersion activity lakes of Bhopal. India Asian J Exp Sci 20(2):289-296

WHO (2004) Guidelines for drinking-water quality, World Health Organization, vol 1, 3rd edn. WHO, Geneva Recommendation

Wilcox LV (1955). Classification and use of irrigation waters. US Department of Agriculture Circular No. 969 